\title{
Pengaruh Profitabilitas, Leverage, Dan Likuiditas Terhadap Ketepatan Waktu Penyajian Laporan Keuangan Pada Perusahaan Subsektor Perdagangan Eceran yang Terdaftar Di Bursa Efek Indonesia Tahun 2015-2019
}

\author{
Reza Budi Pratomo ${ }^{1}$, Munari ${ }^{2}$ \\ ${ }^{1}$ Universitas Pembangunan Nasional "Veteran" Jawa Timur \\ e-mail: 17013010304@student.upnjatim.ac.id \\ ${ }^{2}$ Universitas Pembangunan Nasional "Veteran" Jawa Timur \\ e-mail: munari.ak@upnjatim.ac.id
}

\section{ARTICLE INFO}

Article history:

Received 30 September 2021

Received in revised form 2 November 2021

Accepted 10 November 2021

Available online 1 Desember 2021
The purpose of this research is to test and prove the factors that influence the timeliness of the company's financial reporting. The variables used in this study are profitability, leverage, and liquidity as independent variables, while the timeliness of the presentation of financial statements as the dependent variable. The population in this case research is a retail trade sub-sector company registered in Indonesia Stock Exchange 2015-2019. This study uses secondary data obtained from www.idx.co.id and related company websites. The data taken is company data for the 2015-2019 period with using purposive sampling, so that the total sample obtained is 7 companies. The analysis technique in this research is multiple linear regression analysis using SPSS 25 software. The results showed that profitability and leverage did not affect the timeliness of the presentation of financial statements, while liquidity affects the timeliness of financial statement presentation.

Keywords: Timeliness, profitability, leverage, and liquidity.

\section{ABSTRACT}

\section{Pendahuluan}

Tingkat pertumbuhan ekonomi di Indonesia mengalami penurunan akibat wabah Covid-19 pada akhir tahun 2019. Wabah ini sangat berdampak besar bagi seluruh aspek khususnya pada sektor perekonomian. Banyak pertumbuhan perusahaan yang tidak bisa diprediksi selama adanya pandemi Covid-19, oleh karena itu informasi pendukung yang bisa investor dapatkan dalam mengambil keputusan adalah informasi detail mengenai kinerja perusahaan.

Banyaknya perusahaan yang pailit karena tidak dapat bertahan dalam kondisi ini, sehingga mengakibatkan ketidak tepat waktuan dalam menyampaikan laporan keuangan tahunan di BEI. Termasuk pada sektor perdagangan, jasa, dan investasi yang menjadi dasar semua kebutuhan masyarakat, seperti pendidikan, kesehatan, dan pariwisata. 
Peningkatan pada bidang ekspor impor mencapai 7,67 dan 21,3 persen di kuartal 1/2020 (Sapitri 2021). Disebut perolehan tertinggi pada sektor perdagangan dikarenakan saat kuartal 1/2020 turun hingga $-7,59$ persen. Dibuktikan pada kuartal II/2021 sektor perdagangan besar dan eceran terjadi kemajuan pesat sebesar 9,44 persen yoy (Fauzan 2021). Rumah tangga disebut menjadi konsumsi tertinggi di Indonesia yaitu sebesar 57,6 persen (Sucipto 2021).

Pertumbuhan perusahaan tidak bisa diprediksi selama adanya pandemi covid-19, sehingga investor membutuhkan penunjang pengambilan keputasan berupa informasi tentang kinerja perusahaan. Informasi yang menjadi acuan bagi pihak internal maupun eksternal yaitu informasi keuangan. Dalam bidang akuntansi, informasi keuangan sering disebut dengan laporan keuangan. Laporan keuangan merupakan dokumen yang menggambarkan kondisi keuangan perusahaan dalam periode tertentu secara rinci. Ketepatan waktu penyajian laporan keuangan merupakan kontribusi terpenting bagi pihak-pihak yang membutuhkan (Srimindarti 2008). Karena mengandung banyak manfaat sebagai rekomendasi dalam mengambil keputusan. Ketika perusahaan telat menyampaikan laporan keuangan, maka makna inti sari laporan keuangan semakin berkurang

Laporan keuangan dianggap sangat bermanfaat jika perusahaan tepat dan cepat dalam mempublish laporan keuangan dari segi kualitas dan waktu sehingga manfaat yang diperoleh sangat baik (Almilia and Setiady 2006). Namun, ketika terlambat maka informasi didalamnya menjadi kurang bermanfaat dan tidak dapat menunjang penuh keputusan-keputusan ekonomi yang akan diambil.

Tuntutan akan kepatuhan terhadap ketepatan waktu dalam menyampaikan laporan keuangan perusahaan publik di Indonesia telah diatur dalam UU No. 8 Tahun 1995 tentang pasar modal. Pada tahun 1996, Bapepam juga mengeluarkan Lampiran keputusan Ketua Bapepam Nomor: 80/PM/1996 tentang kewajiban bagi setiap emiten dan perusahaan publik untuk menyampaikan laporan keuangan tahunan perusahaan dan laporan audit independennya kepada Bapepam selambat-lambatnya pada akhir bulan keempat (120 hari) setelah tanggal laporan keuangan tahunan perusahaan. Kemudian diperketat dengan dikeluarkannya Kep17/PM/2002 dan telah diperbaharui dengan Peraturan Bapepam Nomor X.K.2, lampiran Keputusan Ketua Bapepam Nomor: Kep-36/PM/2003 yang menyatakan bahwa laporan keuangan tahun harus disertai dengan laporan akuntan dengan pendapat yang lazim dan disampaikan kepada Bapepam selambat-lambatnya pada akhir bulan ketiga ( 90 hari) setelah tanggal laporan keuangan tahunan.

Berdasarkan berita yang diperoleh dari (cnbcIndonesia.com 2020) terdapat perusahaan yang telat menyajikan laporan keuangan auditan per 31 Desember 2019 dan tidak membayar kompensasi mengenai telat waktu penyajian laporan keuangan.

Tabel 1

Perusahaan Sub Sektor Perdagangan Eceran yang Telat Publish Laporan Keuangan

\begin{tabular}{|c|c|l|l|}
\hline No. & Kode & \multicolumn{1}{|c|}{$\begin{array}{c}\text { Nama Perusahaan } \\
\text { Tercatat }\end{array}$} & \multicolumn{1}{|c|}{ Status Perdagangan Efek } \\
\hline 1. & RIMO & $\begin{array}{l}\text { Rimo International } \\
\text { Lestari Tbk }\end{array}$ & $\begin{array}{l}\text { Suspensi diseluruh pasar sejak 11 Februari } \\
\text { 2020. }\end{array}$ \\
\hline 2. & SKYB & Skybee Tbk & $\begin{array}{l}\text { Suspensi di pasar regular dan tunai sejak 17 } \\
\text { Februari 2020. }\end{array}$ \\
\hline 3. & TELE & $\begin{array}{l}\text { Tiphone Mobile } \\
\text { Indonesia Tbk }\end{array}$ & Suspensi diseluruh pasar sejak 10 Juni 2020. \\
\hline 4. & TRIO & Trikomsel Oke Tbk & $\begin{array}{l}\text { Suspensi di pasar regular dan tunai sejak 17 Juli } \\
2019 .\end{array}$ \\
\hline
\end{tabular}

Sumber: www.cnbcindonesia.com

Fakta telah menunjukkan banyak terjadi kasus keterlambatan penyampaian laporan keuangan oleh perusahaan yang go public di Indonesia. BEI mencatat ada sebanyak 26 kasus secara keseluruhan namun hanya 4 kasus dalam perusahaan sub sektor perdagangan eceran yang melakukan pelanggaran ditahun 2019. Pelanggaran tersebut mulai dari keterlambatan penyampaian laporan keuangan hingga transaksi efek di bursa. Karena hal tersebut, cara investor untuk menilai kesehatan sebuah perusahaan salah satunya dengan melihat profitabilitas, leverage, dan likuiditas. Setiap perusahaan pasti memiliki tingkat profitabilitas, leverange, dan likuiditas yang berbeda-beda akibat dari kegiatan operasi yang dilakukan.

JURNAL ILMIAH KOMPUTERISASI AKUNTANSI Vol. 14, No. 2, Desember 2021 :275 - 282 
Profitabilitas merupakan suatu hal yang penting karena dapat menunjukkan apakah perusahaan tersebut memiliki prospek yang baik atau tidak di masa yang akan datang (Novyanny and Turangan n.d.). Sedangkan likuiditas dapat menggambarkan kemampuan perusahaan untuk memenuhi kewajiban jangka pendek ketika perusahaan mengalami financial distress atau saat perusahaan akan dilikuditasi maupun untuk membiayai kegiatan operasional perusahaan sebagai modal kerja. Likuiditas memiliki hubungan yang erat dengan profitabilitas karena likuiditas dapat memperlihatkan tingkat ketersediaan modal kerja yang dibutuhkan dalam aktivitas operasional. Di samping unsur likuiditas yang dapat mempengaruhi profit perusahaan, leverage menggambarkan perbandingan kewajiban dan ekuitas dalam pendanaan perusahaan dan menunjukkan kemampuan modal sendiri perusahaan tersebut untuk memenuhi seluruh kewajibannya (Afriyeni and Marlius 2019).

Setiap perusahaan pasti memiliki tingkat profitabilitas, leverange, dan likuiditas yang berbedabeda akibat dari kegiatan operasi yang dilakukan oleh perusahaan. Apabila profitabilitas perusahaan baik, maka para stakeholders akan melihat sejauh mana perusahaan dapat menghasilkan laba dari penjualan dan investasi. Semakin baik kinerja perusahaan akan meningkatkan nilai perusahaan.

Namun, terdapat hasil penelitian yang tidak konsisten mengenai hubungan profitabilitas dengan ketepatan waktu penyajian laporan keuangan. Berdasarkan (Effendi 2019) profitabilitas berpengaruh negatif atau tidak berpengaruh signifikan terhadap ketepatan waktu pelaporan keuangan. Hal ini dikarenakan perusahaan tidak mempertimbangkan tingkat profitabilitas yang dimiliki oleh perusahaan tersebut. Perusahaan yang profitabilitasnya tinggi atau rendah sama-sama ingin menyampaikan laporan keuangan tepat waktu tanpa melihat tingkat profitabilitas yang dimiliki perusahaan. Sedangkan penelitian yang dilakukan oleh (Yusuf 2019) menyatakan bahwa profitabilitas berpengaruh terhadap ketepatan waktu penyampaian laporan keuangan, berarti semakin tinggi tingkat profitabilitas berpengaruh terhadap semakin tingginya tingkat ketepatan waktu penyampaian laporan keuangan.

Selain profitabilitas, juga terdapat salah satu aspek lain yang dapat berengaruh terhadap ketepatan waktu penyajian laporan keuangan yaitu leverage. Leverage adalah cerminan dari struktur modal perusahaan. Kesulitan keuangan merupakan berita buruk bagi perusahaan, sehingga perusahaan dengan kondisi seperti ini cenderung terlambat dalam menyampaikan laporan keuangannya (Utari and Amin 2011).

Berdasarkan penelitian (Permana 2009) menunjukkan perusahaan dengan DER yang tinggi belum tentu akan menunda penyampaian laporan keuangannya yang berakibat tidak tepat waktunya penyampaian laporan keuangan perusahaan tersebut. Namun, berbeda dari hasil dari penelitian (Utari \& Amin, 2011) menunjukkan bahwa leverage keuangan memiliki pengaruh yang signifikan terhadap ketepatan waktu penyampaian laporan keuangan dikarenakan kesulitan keuangan merupakan berita buruk bagi perusahaan, sehingga perusahaan dengan kondisi seperti ini cenderung terlambat dalam menyampaikan laporan keuangannya.

Aspek terakhir dalam penentuan ketepatan waktu penyajian laporan keuangan adalah likuiditas. Perusahaan yang bisa membayar hutang tepat pada waktunya artinya keadaan perusahaan likuid, dan perusahaan dikatakan mampu memenuhi kewajiban keuangan tepat pada waktunya apabila perusahaan tersebut mempunyai instrumen pembayaran ataupun current asset yang lebih besar dari pada hutang lancarnya atau hutang jangka pendek.

Berdasarkan penelitian (Mareta 2015) tingkat likuiditas yang tinggi tidak menjamin perusahaan menyampaikan laporan keuangannya tepat waktu. Oleh karena itu, perusahaan yang tepat waktu maupun perusahaan yang tidak tepat waktu sebagian besar melaporkan laporan keuangan secara tepat waktu untuk menghindari persepsi negatif oleh kreditor terhadap kinerja perusahaan. Berbeda hasil dari penelitian (Fili and Wahyuningsih 2020) yang menunjukkan bahwa current ratio memiliki pengaruh signifikan terhadap ketepatan waktu pelaporan keuangan, artinya semakin tinggi aset lancar yang dipunyai perusahaan untuk membiayai hutang lancar perusahaan maka perusahaan itu akan lebih tepat waktu dalam menyampaikan laporan keuangannya.

Merujuk permasalahan, peneliti mencoba untuk menguji dan membuktikan profitabilitas, leverage, dan likuiditas berpengaruh terhadap ketepatan waktu penyajian laporan keuangan. Pembeda penelitian ini dapat dilihat dari populasi, yaitu menggunakan perusahaan sub sektor perdagangan eceran yang terdaftar di Bursa Efek Indonesia (BEI) pada tahun 2015-2019 untuk populasi dan menggunakan software SPSS versi 25.

Pengaruh Profitabilitas, Leverage, Dan Likuiditas Terhadap Ketepatan Waktu Penyajian Laporan Keuangan Pada Perusahaan Subsektor Perdagangan Eceran yang Terdaftar Di Bursa Efek Indonesia Tahun 2015-2019 (Reza Budi Protomo) 
Berdasarkan pada konsep teori keagenan, penyampain laporan keuangan diharuskan tepat waktu supaya agen dan prinsipal tidak mendatangkan asimetri dari kedua pihak (Zahroh 2018). Sedangkan menurut teori kepatuhan, teori ini mewajibkan semua perusahaan yang terdaftar di BEI untuk segera menyajikan laporan keuangan dengan batas waktu sesuai peraturan perundang-undangan, yaitu paling lambat 90 hari setelah tanggal laporan keuangan (Effendi, 2019). Sehingga hipotesis yang dibangun yaitu:

$\mathrm{H}_{1}$ : Profitabilitas berpengaruh signifikan terhadap ketepatan waktu penyajian laporan keuangan.

$\mathrm{H}_{2}$ : Leverage berpengaruh signifikan terhadap ketepatan waktu penyajian laporan keuangan.

$\mathrm{H}_{3}$ : Likuiditas berpengaruh signifikan terhadap ketepatan waktu penyajian laporan keuangan.

\section{Metode Penelitian}

Riset ini terkategorikan penelitian kuantitatif yang memiliki tujuan untuk melihat keterkaitan antar variabel. Populasi menggunakan perusahaan sub sektor perdagangan eceran yang terdaftar di BEI tahun 2015-2019 dengan jumlah 25 perusahaan. Objek penelitian menggunakan laporan keuangan tahunan perusahaan sub sektor perdagangan eceran yang terdaftar di BEI tahun 2015-2019. Lalu untuk sampel penelitian menggunakan metode purposive sampling dengan beberapa kriteria sebagai berikut:

1. Perusahaan sub sektor Perdagangan Eceran yang terdaftar di BEI tahun 2015-2019.

2. Perusahaan sub sektor Perdagangan Eceran yang telah menerbitkan laporan tahunan lengkap selama periode pengamatan pada Bursa Efek Indonesia tahun 2015-2019.

3. Perusahaan sub sektor Perdagangan Eceran yang terdaftar di BEI tahun 2015-2019 yang menyajikan laporan keuangan menggunakan mata uang rupiah sebagai mata uang pelaporan.

4. Perusahaan sub sektor Perdagangan Eceran yang tidak mengalami kerugian konstan selama terdaftar pada Bursa Efek Indonesia tahun 2015-2019.

Semua data yang terkumpul akan diuji dengan software SPSS versi 25 dan menggunakan analisis regresi linier berganda.

\section{Hasil dan Pembahasan}

3.1. Hasil

\subsubsection{Statistik Deskriptif}

Tabel 2 Statistik Deskriptif

Descriptive Statistics

\begin{tabular}{|l|c|c|c|c|c|}
\hline & $\mathrm{N}$ & Minimum & Maximum & Mean & Std. Deviation \\
\hline ROA & 35 & .03 & 45.80 & 10.4240 & 11.98463 \\
\hline DER & 35 & .20 & 4.29 & 1.5697 & 1.17573 \\
\hline CR & 35 & .72 & 8.10 & 2.2257 & 2.04793 \\
\hline $\begin{array}{l}\text { KETEPATAN } \\
\text { WAKTU }\end{array}$ & 35 & 0 & 1 & .94 & .236 \\
\hline Valid N (listwise) & 35 & & & & \\
\hline
\end{tabular}

Sumber: Data diolah, 2021

Berdasarkan tabel 1, variabel indepen berupa profitabilitas (ROA), dari 35 sampel memiliki nilai terendah 0,03 dan nilai tertinggi 45,80. Rata-rata sebesar 10.4240, dengan standar deviasi sebesar 11.98463 .

Variabel indepen lainnya berupa leverage (DER), memiliki nilai terendah 0,20 dan nilai tertinggi 4.29. Rata-rata sebesar 1.5697 dengan standar deviasi sebesar 1.17573.

Variabel likuiditas, memiliki nilai terendah 0,72 dan nilai tertinggi 8.10. Ratarata sebesar 2.2257, dengan standar deviasi 2.04793.

Variabel dependen berupa ketepatan waktu penyajian laporan keuangan, memiliki nilai terendah 0 dan nilai tertinggi 1 . Rata-rata dari ketepatan waktu adalah 0,94 , dengan standar deviasi sebesar 0,236. 


\subsubsection{Uji Normalitas}

Tabel 3 Hasil Uji Normalitas

One-Sample Kolmogorov-Smirnov Test

\begin{tabular}{|llc|c|c|c|}
\hline & & $\mathrm{X} 1$ & $\mathrm{X} 2$ & $\mathrm{X} 3$ & $\mathrm{Y}$ \\
\hline $\mathrm{N}$ & & 35 & 35 & 35 & 35 \\
\hline Normal Parameters & & & & \\
& Mean & 10.4240 & 1.5697 & 2.2257 & .9429 \\
\cline { 2 - 6 } & Std. Deviation & 11.98463 & 1.17573 & 2.04793 & .23550 \\
\hline Most Extreme & Absolute & .211 & .126 & .310 & .539 \\
\cline { 2 - 6 } Differences & Positive & .211 & .126 & .310 & .404 \\
\cline { 2 - 6 } & Negative & -.193 & -.122 & -.231 & -.539 \\
\hline Test Statistic & & .211 & .126 & .310 & .539 \\
\hline Asymp. Sig. (2-tailed) & & $.000^{\mathrm{c}}$ & $.177^{\mathrm{c}}$ & $.000^{\mathrm{c}}$ & $.000^{\mathrm{c}}$ \\
\hline
\end{tabular}

Sumber: Data diolah, 2021

Nilai awal pengujian menunjukkan nilai Monte Carlo Sig. (2-tailed) <.05 dapat diartikan bahwa data outliers/residual tidak terdistribusi normal dan model regresi gagal memenuhi normalitas.

Agar mencapai normalitas, maka data harus dibuat normal dengan cara mengeliminasi data outliers/residual. Setelah melalui tahap pengeliminasi data outliers/residual, dilakukan pengujian One-Sample Kolmogorov-Smirnov kembali. Hasil dari pengujian ulang ditunjukkan dalam tabel berikut:

Tabel 4 Hasil Pengujian Kembali Uji Normalitas One-Sample Kolmogorov-Smirnov Test

\begin{tabular}{|c|c|c|c|c|c|c|}
\hline & & & $\mathrm{X} 1$ & $\mathrm{X} 2$ & $\mathrm{X} 3$ & $\bar{Y}$ \\
\hline $\mathrm{N}$ & & & 28 & 28 & 28 & 28 \\
\hline \multirow[t]{2}{*}{ Normal Parameters ${ }^{\mathrm{a}, \mathrm{b}}$} & \multicolumn{2}{|l|}{ Mean } & 6.6764 & 1.7721 & 1.5000 & .9643 \\
\hline & \multicolumn{2}{|l|}{ Std. Deviation } & 8.54422 & 1.15549 & .81217 & .18898 \\
\hline \multirow{3}{*}{$\begin{array}{l}\text { Most Extreme } \\
\text { Differences }\end{array}$} & \multicolumn{2}{|l|}{ Absolute } & .229 & .144 & .250 & .539 \\
\hline & \multicolumn{2}{|l|}{ Positive } & .229 & .144 & .250 & .425 \\
\hline & \multicolumn{2}{|l|}{ Negative } & -.218 & -.111 & -.168 & -.539 \\
\hline \multicolumn{2}{|l|}{ Test Statistic } & & .229 & .144 & .250 & .539 \\
\hline \multicolumn{2}{|l|}{ Asymp. Sig. (2-tailed) } & & $.001^{\mathrm{c}}$ & $.145^{\mathrm{c}}$ & $.000^{\mathrm{c}}$ & $.000^{\mathrm{c}}$ \\
\hline \multirow{3}{*}{$\begin{array}{l}\text { Monte Carlo Sig. (2- } \\
\text { tailed) }\end{array}$} & Sig. & & $.091^{\mathrm{d}}$ & $.567^{\mathrm{d}}$ & $.052^{\mathrm{d}}$ & .000 \\
\hline & \multirow{2}{*}{$\begin{array}{l}\text { 99\% Confidence } \\
\text { Interval }\end{array}$} & Lower Bound & .083 & .554 & .046 & .000 \\
\hline & & Upper Bound & .098 & .580 & .058 & .000 \\
\hline
\end{tabular}

Sumber: Data diolah, 2021

Nilai akhir pengujian menunjukkan nilai Monte Carlo Sig. (2-tailed) > .05 dapat diartikan bahwa data outliers/residual telah terdistribusi normal dan model regresi memenuhi normalitas.

\subsubsection{Uji Multikolinearitas}

Tabel 5 Hasil Uji Multikolinearitas

Coefficients $^{\text {a }}$

\begin{tabular}{|c|c|c|}
\hline & Collinearity Statistics & Ketoronaron \\
\hline Model & Tolerance & ngan \\
\hline
\end{tabular}

Pengaruh Profitabilitas, Leverage, Dan Likuiditas Terhadap Ketepatan Waktu Penyajian Laporan Keuangan Pada Perusahaan Subsektor Perdagangan Eceran yang Terdaftar Di Bursa Efek Indonesia Tahun 2015-2019 (Reza Budi Protomo) 


\begin{tabular}{|llll|}
\hline 1 (Constant) & & & \\
X1 & .950 & 1.052 & Tidak terjadi multikolinieritas \\
X2 & .486 & 2.058 & Tidak terjadi multikolinieritas \\
X3 & .503 & 1.987 & Tidak terjadi multikolinieritas \\
\hline
\end{tabular}

Sumber: Data diolah, 2021

Dari tabel hasil ke 5 dapat dilihat bahwa nilai VIF tiga variabel independen $(1,052 ; 2,058$; dan 1,987) < 10 dan nilai tolerance dari ketiga variabel independen $(0,950 ; 0,486$; dan 0,503$)>0,1$ sehingga disimpulkan bahwa tidak ada multikolinearitas antara variabel independen.

\subsubsection{Uji Autokorelasi}

Tabel 6 Hasil Uji Autokorelasi

Model Summary

\begin{tabular}{|cccccc|}
\hline Model & $\mathrm{R}$ & R Square & Adjusted R Square & $\begin{array}{c}\text { Std. Error of } \\
\text { the Estimate }\end{array}$ & Durbin-Watson \\
\hline 1 & $.510^{\mathrm{a}}$ & .260 & .168 & .17242 & 1.391 \\
\hline
\end{tabular}

Sumber: Data diolah, 2021

Menurut tabel hasil uji diperoleh nilai Durbin-Watsnon stat yaitu sebesar 1,391. Berdasarkan tabel durbin watson pada jumlah sampel 28 dengan 3 variabel diperoleh nilai dL sebesar 1,18051 dan nilai dU sebesar 1,65025. Oleh karena itu du $(1,55964)>d$ $(1,391)<4$-du (2,34975) sehingga dapat disimpulkan bahwa model mengandung autokorelasi.

\subsubsection{Uji Heteroskedastisitas}

Tabel 7 Hasil Uji Heteroskedastisitas

Coefficients $^{\mathrm{a}}$

\begin{tabular}{|llccccc|}
\hline Model & \multicolumn{2}{c}{$\begin{array}{c}\text { Unstandardized } \\
\text { Coefficients }\end{array}$} & $\begin{array}{c}\text { Standardized } \\
\text { Coefficients } \\
\text { Beta }\end{array}$ & $\mathrm{t}$ & Sig. \\
& $\mathrm{B}$ & Std. Error & Beta & \\
\hline 1 & (Constant) & 1.261 & .156 & & 8.073 & .000 \\
& X1 & -.002 & .004 & -.088 & -.486 & .631 \\
X2 & -.036 & .041 & -.222 & -.881 & .387 \\
X3 & -.146 & .058 & -.629 & -2.541 & .018 \\
\hline
\end{tabular}

Sumber: Data diolah, 2021

Berdasar hasil perhitungan tabel 7 menunjukkan bahwa model regresi yang dipergunakan pada probabilitas X1 dan X2 tingkat signifikasinya di atas 0,05 artiya tidak mengalami heteroskedastisitas. Sedangkan pada X3 tingkat signifikannya di bawah 0,05 artiya mengalami heteroskedastisitas.

\subsubsection{Analisis Regresi Linier Berganda}

Tabel 8 Hasil Analisis Regresi Linier Berganda

Coefficients $^{\mathbf{a}}$

\begin{tabular}{|llccccc|}
\hline & & \multicolumn{2}{c}{ Unstandardized } & \multicolumn{2}{c|}{$\begin{array}{c}\text { Standardized } \\
\text { Model }\end{array}$} & \multicolumn{2}{c|}{ Coefficients } & Coefficients & $\mathrm{t}$ & Sig. \\
& $\mathrm{B}$ & Std. Error & Beta & & \\
\hline 1 & (Constant) & 1.261 & .156 & & 8.073 & .000 \\
& X1 & -.002 & .004 & -.088 & -.486 & .631 \\
X2 & -.036 & .041 & -.222 & -.881 & .387 \\
X3 & -.146 & .058 & -.629 & -2.541 & .018 \\
\hline
\end{tabular}

JURNAL ILMIAH KOMPUTERISASI AKUNTANSI Vol. 14, No. 2, Desember $2021: 275$ - 282 
Sumber: Data diolah, 2021

Dari tabel tersebut didapatkan persamaan regresi sebagai berikut:

$$
Y=1.261-0,002 X_{1}-0,036 X_{2}-0,146 X_{3}
$$

Penjelasan persamaan regresi diatas yaitu :

a. Konstanta $(\beta 0)$

Dengan nilai sebesar 1.261 menunjukan apabila profitabilitas, leverage, dan likuiditas tidak berubah, nilai ketepatan waktu penyajian laporan keuangan (Y) naik sebesar 1.261 satuan.

b. Koefisien regresi $(\beta 1)$

Dengan nilai sebesar $-0,002,(\beta 1)$ negatif mengartikan tidak ada hubungan yang searah antara nilai ketepatan waktu penyajian laporan keuangan dengan profitabilitas, artinya apabila profitabilitas naik sebesar 1 satuan, nilai ketepatan waktu penyajian laporan keuangan turun sebesar 0,002satuan.

c. Koefisien regresi $(\beta 2)$

Dengan nilai sebesar $-0,036$, $(\beta 2)$ negatif mengartikan tidak ada hubungan yang searah antara nilai ketepatan waktu penyajian laporan keuangan dengan leverage, artinya apabila profitabilitas naik sebesar 1 satuan, nilai ketepatan waktu penyajian laporan keuangan turun sebesar 0,036 satuan.

d. Koefisien regresi $(\beta 3)$

Dengan nilai sebesar $-0,146,(\beta 3)$ negatif mengartikan tidak ada hubungan yang searah antara nilai ketepatan waktu penyajian laporan keuangan dengan likuiditas, artinya apabila profitabilitas naik sebesar 1 satuan, nilai ketepatan waktu penyajian laporan keuangan turun sebesar 0,146 satuan.

\subsubsection{Uji Koefisien Determinasi (Uji $\left.\mathbf{R}^{2}\right)$}

Tabel 9 Hasil Uji R

Model Summary ${ }^{b}$

\begin{tabular}{|cccccc|}
\hline Model & $\mathrm{R}$ & R Square & Adjusted R Square & $\begin{array}{c}\text { Std. Error of } \\
\text { the Estimate }\end{array}$ & Durbin-Watson \\
\hline 1 & $.510^{\mathrm{a}}$ & .260 & .168 & .17242 & 1.391 \\
\hline
\end{tabular}

Sumber: Data diolah, 2021

menurut perhitungan di atas, dapat dilihat bahwa nilai R Square adalah sebesar 0,260. Hal ini dapat diartikan bahwa variabel independen Profitabilitas, Leverage, dan Likuiditas dapat menjelaskan variabel dependen Ketepatan Waktu sebesar 26\%, sedangkan sisanya $(100 \%-26 \%=74 \%)$ diterangkan oleh sebab-sebab lain diluar model.

\subsubsection{Uji Kesesuaian Model (Uji F)}

Tabel 10 Hasil Uji F

ANOVA $^{\mathrm{a}}$

\begin{tabular}{|llccccc|}
\hline Model & Sum of Squares & df & Mean Square & F & Sig. \\
\hline 1 & Regression & .251 & 3 & .084 & 2.811 & $.061^{\mathrm{b}}$ \\
& Residual & .714 & 24 & .030 & &
\end{tabular}

Pengaruh Profitabilitas, Leverage, Dan Likuiditas Terhadap Ketepatan Waktu Penyajian Laporan Keuangan Pada Perusahaan Subsektor Perdagangan Eceran yang Terdaftar Di Bursa Efek Indonesia Tahun 2015-2019 (Reza Budi Protomo) 


Lotal $\quad .964 \quad 27$

Sumber: Data diolah, 2021

Menurut uji di atas didapatkan nilai $\mathrm{F}$ hitung sebesar 2,811 dengan angka signifikansi sebesar $0,061(>0.05)$, yang mengartikan bahwa model regresi yang dihasilkan tidak sesuai dalam melihat pengaruh dari, Profitabilitas, Leverage dan Likuiditas terhadap Ketepatan Waktu Penyajian Laporan Keuangan pada perusahaan subsektor perdagangn eceran di BEI.

\subsubsection{Uji Parsial (Uji T)}

Tabel 11 Hasil Uji T

Coefficients $^{\mathrm{a}}$

\begin{tabular}{|llccccc|}
\hline & Model & \multicolumn{2}{c}{$\begin{array}{c}\text { Unstandardized } \\
\text { Coefficients } \\
\text { Std. Error }\end{array}$} & $\begin{array}{c}\text { Standardized } \\
\text { Coefficients } \\
\text { Beta }\end{array}$ & T & Sig. \\
\hline 1 & (Constant) & 1.261 & .156 & & 8.073 & .000 \\
& X1 & -.002 & .004 & -.088 & -.486 & .631 \\
X2 & -.036 & .041 & -.222 & -.881 & .387 \\
X3 & -.146 & .058 & -.629 & -2.541 & .018 \\
\hline
\end{tabular}

Sumber: Data diolah, 2021

1. Hipotesis satu $\left(\mathrm{H}_{1}\right)$

Berdasarkan tabel 5 besarnya t hitung $X_{1}$ sebesar $-0,486$, dengan tingkat sig. 0.631 $(>0.05)$, artinya profitabilitas tidak berpengaruh terhadap ketepatan waktu penyajian laporan keuangan $(\mathrm{Y})$.

2. Hipotesis dua $\left(\mathrm{H}_{2}\right)$

Berdasarkan tabel 5 menunjukan besarnya t hitung $\mathrm{X}_{2}$ sebesar $-0,881$, dengan tingkat sig. 0,387 (>0.05), artinya leverage tidak berpengaruh terhadap ketepatan waktu penyajian laporan keuangan (Y)

3. Hipotesis tiga $\left(\mathrm{H}_{3}\right)$

Berdasarkan tabel 5 besarnya t hitung $\mathrm{X}_{3}$ sebesar 2,541, dengan tingkat sig. 0,018 $(<0.05)$, artinya likuiditas berpengaruh terhadap ketepatan waktu penyajian laporan keuangan $(\mathrm{Y})$.

\subsection{Pembahasan}

Hipotesis pertama $\left(\mathrm{H}_{1}\right)$, menyatakan profitabilitas tidak berpengaruh terhadap ketepatan waktu pelaporan keuangan. Artinya $\mathrm{H}_{1}$ ditolak. Sejalan dengan hasil penelitian dari (Effendi 2019) profitabilitas berpengaruh negatif terhadap ketepatan waktu penyajian laporan keuangan. Disebabkan karena profitabilitas tidak dipertimbangkan oleh perusahaan. Karena sesungguhnya laporan keuangan perusahaan ingin menyampaikan tepat waktu tidak tergantung tinggi rendahnya profitabilitas

Hipotesis kedua $\left(\mathrm{H}_{2}\right)$, menjelaskan bahwa leverage tidak memiliki pengaruh terhadap ketepatan waktu penyajian laporan keuangan. Artinya $\mathrm{H}_{2}$ ditolak. Penelitian sejalan dengan penelitian (Permana 2009) menunjukkan perusahaan dengan leverage yang tinggi belum tidak ada jaminan untuk telat dalam menyampaian laporan keuangannya.

Hipotesis ke tiga $\left(\mathrm{H}_{3}\right)$, menyatakan likuiditas memiliki pengaruh terhadap ketepatan waktu penyajian laporan keuangan. Artinya $\mathrm{H}_{3}$ diterima. Penelitian sejalan dengan (Fili and Wahyuningsih 2020) yang membuktikan likuiditas berpengaruh terhadap ketepatan waktu penyajian laporan keuangan. Artinya semakin tinggi aset lancar yang dipunyai perusahaan untuk membiayai hutang lancar perusahaan, maka perusahaan itu akan lebih tepat waktu dalam menyampaikan laporan keuangannya. Oleh karena itu besar kecilnya tingkat likuiditas perusahaan ditentukan oleh ketepatan waktu penyampaian laporan keuangan. Perusahaan yang memiliki likuiditas yang besar ingin laporan keuangannya segera dipublikasikan. 


\section{Kesimpulan}

Berdasarkan hasil pengujian dan pembahasan maka didapatkan kesimpulan bahwa:

1. Profitabilitas dan leverage tidak berpengaruh terhadap ketepatan waktu penyajian keuangan perusahaan subsektor perdagangan eceran yang terdaftar di BEI tahun 2015-2019.

2. Likuiditas berpengaruh terhadap ketepatan waktu penyajian keuangan perusahaan subsektor perdagangan eceran yang terdaftar di BEI tahun 2015-2019.

Penelitian selanjutnya diharap menggunakan populasi dari sektor lain. Menambahkan kriteria sampel sehingga dapat memperluas cakupan penelitian dan menambah variabel lainnya agar data yang didapat lebih akurat.

\section{Daftar Pustaka}

Afriyeni, Afriyeni, and Doni Marlius. 2019. “Analisis Faktor-Faktor Yang Berpengaruh Terhadap Ketepatan Waktu Penyampaian Laporan Keuangan Pada Perusahaan Yang Listing Di Bursa Efek Indonesia." (February). doi: 10.31219/osf.io/rv4qf.

Almilia, Luciana Spica, and Lucas Setiady. 2006. "Faktor - Faktor Yang Mempengaruhi Penyelesaian Penyajian Laporan Keuangan Pada Perusahaan Yang Terdaftar Di BEJ.” Seminar Nasional Good Corporate Governance (November):1-29.

cnbcIndonesia.com. 2020. "Bandel! 26 Emiten Telat Setor Lapkeu 2019, Kena Suspensi Deh.” Retrieved (https://www.cnbcindonesia.com/market/20200831113604-17-183224/bandel-26-emiten-telatsetor-lapkeu-2019-kena-suspensi-deh).

Effendi, Bahtiar. 2019. "Komite Audit, Profitabilitas, Solvabilitas, Dan Ketepatan Waktu Pelaporan Keuangan Perusahaan Manufaktur-Sektor Logam.” Business Innovation \& Entrepreneurship Journal E-ISSN 1.

Fauzan, Rahmad. 2021. "Ini Sektor Yang Dongkrak Laju Pertumbuhan Perdagangan RI Artikel Ini Telah Tayang Di Bisnis.Com Dengan Judul "Ini Sektor Yang Dongkrak Laju Pertumbuhan Perdagangan RI ", Klik Selengkapnya Di Sini: Https://Ekonomi.Bisnis.Com/Read/20210805/12/1426255/IniSe." Bisnis.Com. Retrieved (https://ekonomi.bisnis.com/read/20210805/12/1426255/ini-sektoryang-dongkrak-laju-pertumbuhan-perdagangan-ri).

Fili, Marlina, and Dwi Wahyuningsih. 2020. "PENGARUH RETURN ON ASSETS, CURRENT RATIO, DAN DEBT TO EQUITY RATIO TERHADAP KETEPATAN WAKTU PENYAMPAIAN LAPORAN KEUANGAN Marlina." JCA Ekonomi 1.

Mareta, Sigit. 2015. "ANALISIS FAKTOR-FAKTOR YANG MEMENGARUHI TIMELINESS PUBLIKASI LAPORAN KEUANGAN PERIODE 2009-2010 (Studi Empiris Pada Bursa Efek Indonesia) Sigit." Jurnal Akuntansi XIX.

Novyanny, Maria Cynthia, and Joyce A. Turangan. n.d. "PENGARUH LIKUIDITAS, UKURAN PERUSAHAAN, UMUR PERUSAHAAN DAN PERTUMBUHAN PERUSAHAAN TERHADAP PROFITABILITAS PADA PERUSAHAAN JASA SEKTOR PERDAGANGAN, JASA \& INVESTASI YANG TERDAFTAR PADA BURSA EFEK INDONESIA.”J Jurnal Manajerial Dan Kewirausahaan.

Permana, Syaikhul Hadi. 2009. "PENGARUH PROFITABILITAS, LEVERAGE, LIKUIDITAS DAN UKURAN PERUSAHAAN TERHADAP KETEPATAN WAKTU PENYAMPAIAN LAPORAN KEUANGAN PERUSAHAAN PROPERTI YANG TERDAFTAR DI BEI."

Sapitri, Devi. 2021. "Kerja Sama Untuk Pulihkan Sektor Perdagangan Di Masa Pandemi Covid-19." Kumparan.Com.

Srimindarti, Ceacilia. 2008. "KETEPATAN WAKTU PELAPORAN KEUANGAN OLEH: CEACILIA SRIMINDARTI Fakultas Ekonomi Universitas Stikubank Semarang." Jurnal Ilmiah Akuntansi Dan Bisnis 7(1):14-21.

Sucipto, Heofilus Ifan. 2021. "Pemerintah Diminta Prioritaskan Sektor Perdagangan Eceran.” Medcom.Id. Retrieved (https://www.medcom.id/nasional/politik/0KvgReGN-pemerintah-diminta-prioritaskansektor-perdagangan-eceran).

Utari, Valeda Rohana, and Muhammad Nuryatno Amin. 2011. "PENGARUH PROFITABILITAS,

Pengaruh Profitabilitas, Leverage, Dan Likuiditas Terhadap Ketepatan Waktu Penyajian Laporan Keuangan Pada Perusahaan Subsektor Perdagangan Eceran yang Terdaftar Di Bursa Efek Indonesia Tahun 2015-2019 (Reza Budi Protomo) 
LIKUIDITAS, LEVERAGE KEUANGAN, UKURAN PERUSAHAAN DAN KEPEMILIKAN PUBLIK TERHADAP KETEPATAN WAKTU PELAPORAN KEUANGAN PERUSAHAAN MANUFAKTUR YANG TERDAFTAR DI BURSA EFEK INDONESIA TAHUN 2009 - 2011.” Media Riset Akuntansi, Auditing \& Informasi 11.

Yusuf, Rivaldi Aditya. 2019. "PENGARUH PROFITABILITAS, LEVERAGE DAN LIKUIDITAS TERHADAP KETEPATAN WAKTU PENYAMPAIAN LAPORAN KEUANGAN KE OJK PADA PERUSAHAAN PERTAMBANGAN YANG TERDAFTAR DI BEI TAHUN 2014-2016." Zahroh, Yananda Fatimatul. 2018. "PENGARUH DER, PROFITABILITAS, KUALITAS AUDITOR, OPINI AUDIT DAN UKURAN PERUSAHAAN TERHADAP KETEPATAN WAKTU.” Jurnal Ilmu Dan Riset Akuntansi 7. 